Maxine Sheets-Johnstone

\title{
RUCH - PODSTAWA REALNOŚCI ŚWIATA OŻYWIONEGO
}

\section{Wstęp}

Strategie choreograficzne nie zależą tylko od ruchu. Ruch jest integralną częścią ich realizacji. Niezależnie od pola naukowych poszukiwań jest natchniony, a natura, jak uważał Arystoteles, ,jest zasadą ruchu i zmian”. Następnie natychmiast wzywa1: „Skoro badamy przyrodę jako zasadę ruchu i zmian, nie można zapomnieć o definicji ruchu, albowiem nieznajomość istoty ruchu mogłaby doprowadzić w konsekwencji do nieznajomości przyrody" (Fizyka, 200b, w. 12-14). Krótko mówiąc, strategie zrozumienia natury są niechybnie związane z ruchem. To, co jest podstawową i namacalną prawdą dla natury badań, jest podstawową i namacalną prawdą w odniesieniu do charakteru twórczości artystycznej: ona też jest związana $\mathrm{z}$ ruchem. $\mathrm{W}$ obu przypadkach być związanym $\mathrm{z}$ ruchem oznacza być zakotwiczonym w dynamice kinetycznej. Aby zrozumieć ruch, konieczne jest zrozumienie dynamiki, a konkretnie jakościowej dynamiki ruchu fundamentalnej dla życia oraz doświadczeń i wyzwań, które je tworzą. Aby dostrzec tę podstawową jakość ruchu, nie tylko istotne, ale kluczowe jest wyodrębnienie i wyszczegółowienie przeszkód na drodze do jej zrozumienia, czyli sposobów definiowania, opisywania i etykietowania ruchu i aspektów ruchu, które czasem go zasłaniają. W ten sposób możemy wyciągać słuszne wnioski co do paradygmatu strategii choreograficznych - najpierw w badaniach naukowych, a następnie w twórczości artystycznej.

\section{Przeszkody w rozumieniu jakościowej dynamiki ruchu}

Aby zrozumieć ruch, konieczne jest rozumienie dynamiki. Ruch definiowany jest błędnie jako zmiana pozycji. Błędnie dlatego, że definicja ta zakłada, iż przedmiot zostaje przemieszczony - ma pozycję początkową i końcową. Ruch nie jest jednak tożsamy z przemieszczeniem obiektu; powiązany jest on z samym przemieszczeniem. Arystoteles miał rację, stwierdzając, że „natura jest zasadą i wewnętrzną przyczyną ruchu", i wnikliwie spostrzegając, iż zrozumienie natury nie jest możliwe bez uprzedniego zrozumienia, czym jest ruch (Fizyka 200b, w. 12-14). 
Ruch nie jest po prostu siłą $w$ czasie i $w$ przestrzeni. Opisując ruch $\mathrm{w}$ ten sposób, nie oddajemy złożoności jego uwarunkowań przestrzennych, czasowych i energetycznych. Oczywiście nasz spacer ulicą może być postrzegany jako spacer $w$ przestrzeni, który trwa $w$ (określonym) czasie, co więcej, jako spacer, który wymaga dającej się zmierzyć ilości energii i siły. Jednak nasz spacer ulicą jest u swych podstaw zjawiskiem dynamicznym, tworzącym swoją własną przestrzeń, czas i energię w samym procesie trwania i wykonywania czynności. Możemy na przykład dreptać powoli - drobnymi, niepewnymi kroczkami; możemy też pędzić naprzód, z każdym kolejnym krokiem wyciągając nogi najdalej, jak się da; możemy się garbić i zbaczać nagle w prawo; możemy maszerować naprzód krokiem zdecydowanym, pełni wigoru lub krokami nieregularnymi, powłócząc nogami - i tak dalej. Pokrótce nasz ruch ma właściwości przestrzenne, czasowe i energetyczne. Jego dynamika jest nacechowana jakościowo. Ponadto jej kontury jako takie mogą się zmienić w każdej chwili. Może nas zaskoczyć zmierzająca ku nam znajoma postać, możemy przyspieszyć w jej kierunku i rozpostrzeć ramiona, by powitać rozpoznanego w niej przyjaciela. Może nas zniewolić lęk przed zebraniem, na które zdążamy, przez co spowalniamy nasze tempo - możemy przystanąć, a nawet zawrócić. I tak dalej. Jakościowa dynamika naszego ruchu jest zawsze zmienna - możemy ją przekształcać wedle naszej woli.

Jakościowa dynamika ruchu odznacza się ciszą. Przejawia się w pełnej spontaniczności od momentu narodzin, a nawet wcześniej - gdy jako płody kopiemy, ssiemy, falujemy, obracamy się i tak dalej (Furuhjelm, Ingelman-Sundbert, Wirsén 1976). Jak zauważają J.A. Scott Kelso i David Engstrøm, na podstawie swoich szeroko zakrojonych badań nad dynamiką koordynacji - „płód porusza się spontanicznie wewnątrz macicy, (...) odkrywając ramiona i nogi, które zginają i rozciągają się; usta, które otwierają się i zamykają; ciało, które wygina i wykręca się" (Kelso, Engstrøm 2006, s. 105-106). Z czasem owa żywotna dynamika wydaje się zanikać, okryta na poziomie ogólnym oczekiwaniami kulturowymi, a na poziomie szczególnym - językiem. W procesie tym nasze ruchome ciała zaczynają być opisywane w kategoriach „działania”, które wydaje się dwudziestopierwszowiecznym substytutem tego, co dawniej opisywane było w kategoriach „zachowania”. Ruch zostaje pożarty przez ów dyskurs. Chodzenie, rzucanie i kopanie stają się tylko aktem. A jednak takie akty są zjawiskami dynamicznymi, które są jakościowo różne, zarówno w kinestetycznym, jak i kinetycznym doświadczeniu. Oznacza to, że istnieją doświadczenia odczuwalne odmiennie i doświadczenia odmiennie postrzegane lub widziane. Na przykład kiedy sami idziemy, odczuwamy kinestetycznie dynamikę przestrzenno-czasowo-energiczną naszego ruchu, niezależnie od tego, czy jest on apatyczny, powolny czy szybki; niezależnie od tego, czy śmiało zmierzamy do przodu, czy kroczymy nieśmiało; czy jesteśmy pochyleni, czy wyprostowani; czy idziemy prosto, czy się potykamy, i tak dalej. Kiedy doświadczamy chodu innych, doświadczamy ich dynamiki kinetycznej, ich dynamika kinetyczna jest dla nas widoczna. Dynamika, którą kinestetycznie od- 
czuwamy we własnym ruchu, to dynamika, jaką kinetycznie postrzegamy w ruchu innych. Właśnie to spostrzegł Arystoteles, gdy określił ruch jako sensu communis. Innymi słowy: ruch przekracza naszą zdolność zmysłową. Jest to naturalny wymiar wszystkich naszych zmysłów: dotyk wymaga ruchu; zapach wymaga ruchu; smak wymaga ruchu; słuch wymaga ruchu; wzrok wymaga ruchu. Nie powinno być zatem zaskoczeniem, że ruch jest naszym językiem ojczystym, o czym już we wcześniejszych pracach pisałam i co podkreślałam. Uczymy się nie tylko naszych ciał, uczymy się nie tylko poruszać, ale wszystkie nasze zmysły poznają świat poprzez ruch.

Biorąc pod uwagę te niewątpliwe fakty życia, dyskurs w którym ruch zostaje niedostrzeżony, przeoczony, a nawet pozornie pozostawiony w śmietniku, wydaje się niesamowitą negacją rzeczywistości. Przychodzimy na świat $\mathrm{w}$ ruchu; nie rodzimy się drętwi. Bezruch następuje w chwili śmierci: kiedy wszystko się skończy, wewnątrz i na zewnątrz, przestajemy istnieć. Jasnym jest przeto, że życie nie jest serią aktów w większym stopniu niż jest - jak uważano - szeregiem zachowań. Ale nie jest też wyłącznie serią ruchów - noga z przodu, noga z tyłu, ramię nad głową, ramię z boku, skręt tułowia, zginanie tułowia i tak dalej. Przeciwnie, życie jest ciągłą dynamiką całego ciała. Dynamizm całego ciała jest realizowany w synergiach znaczącego ruchu. W rzeczy samej - życie nie jest działaniem ani zachowaniem, ale bezustannym ruchem, bogatym w skutki, który ma swoją wagę, który może być nieuchwytny lub konkretny, niechętny lub zdeterminowany, pobudzony lub nijaki, gwałtowny lub stabilny, ale w każdym razie jest naszym chlebem powszednim w bardzo podstawowym znaczeniu - przebiega przez nasze ciała w skoordynowany sposób, w synergiach znaczącego ruchu, czy spełnia nasze pragnienia, nasze cele, nasze oczekiwania, czy też nas zawodzi.

Modna dziś fascynacja ucieleśnieniami tego czy innego rodzaju jeszcze bardziej odwraca uwagę od ruchu. W istocie „ucieleśnienia” są czymś więcej niż rozproszeniem: są przeszkodą w realizacji tego, kim jesteśmy, a tym samym przeszkodą w uznaniu naszego zasadniczego charakteru. Nie jesteśmy istotami ucieleśnionymi, ale istotami animowanymi (ang. animated - ożywionymi, przyp. tłum.). Jesteśmy rzeczywiście animowani, ponieważ jesteśmy przede wszystkim istotami poruszającymi się. Podobnie jak 100 milionów innych gatunków na tej ziemi, my ludzie należymy do królestwa zwierząt. W dzisiejszych kręgach akademickich fakt ten jest dziwnie ignorowany, pozornie w imię wywyższenia ludzi do specjalnego wymiaru ewolucji, wymiaru „ucieleśnień”, jak w „ucieleśnionej podmiotowości”, „ucieleśnionym języku”, „ucieleśnionym ja”, „ucieleśnionych emocjach”, a nawet - cud nad cudami! - „ucieleśnionym ruchu”. Dodanie przymiotnika „ucieleśniony” do tematu lub przedmiotu naszych badań z automatu przydaje mu miejsce w świecie, poprzez zwykły akt zapakowania go w trwały pojemnik. Niestety jest to miejsce, które pozostaje niezauważone, nieopisane, nieoświetlone. Niemniej jednak, biorąc pod uwagę, jak stałe jest to miejsce w świecie - język, podmiotowość, jaźń, emocje oraz ruch otrzymują dom, 
w którym mogą zamieszkać. Nie unoszą się już w jakimś nieokreślonym bycie, ale są bezpieczne, przywiązane do czegoś znaczącego, mianowicie ciała. Niewątpliwie błędem jest uosabianie podmiotowości, języka i reszty. Słowo „ucieleśnienie” dawniej oznaczało „nadanie konkretnej formy”, „uczynienie cielesnym [corporeal]”, „dostarczenie lub włączenie w ciało/a”. Mówimy na przykład, że ktoś jest uosobieniem odwagi lub złem wcielonym. Czy ma jednak sens mówienie, że ktoś uosabia podmiotowość, jaźń lub język? Co więcej, czy ma sens mówienie, że uczucia, emocje lub ruch są ucieleśniane, kiedy pochodzą z ciała? Krótko mówiąc: czy nadanie im ciała nie jest tautologią, gdy są już one cielesnym faktem życia? Czy w efekcie nie byłoby rozsądniejsze myśleć, że powinniśmy drążyć głębiej, odkrywać i wyjaśniać rzeczywiste, cielesne pochodzenie i naturę wszystkich tak zwanych „ucieleśnionych” aspektów ludzkiego życia?

„Ucieleśniona symulacja”, termin lubiany przez Vittorio Gallesego, odkrywcę neuronów lustrzanych, a także przez ich entuzjastów, stwarza szczególny problem w odniesieniu do ruchu i tańca, a właściwie do sztuki w ogóle. O tym szczególnym problemie będziemy jeszcze mówić. Ważne jest jednak uprzednie podkreślenie znaczenia nieodłącznej dynamiki naszej animacji [ożywienia - red.], w szczególności tego, jak ta nieodłączna dynamika odbija się afektywnie i kinestetycznie na naszym życiu niemowlęcym, jak stanowi nasze życie i jak faktycznie opisuje naturę umysłu i świadomości. W tym szerszym kontekście chciałabym najpierw przytoczyć wyniki badań psychiatry dziecięcego i psychologa klinicznego Daniela Sterna, którego opisy tego, co określa „afirmującą/harmonizującą odpowiedzią”, są szczególnie istotne. Są one bowiem zakorzenione w opisach ciszy bez bezruchu - w opisach sposobów, w jakich dynamika ruchu odnosi się bezpośrednio do uczuć, emocji i w ogóle do dynamiki wpływu i percepcji. Oto dwa przykłady:

Dziewięciomiesięczny chłopiec uderza ręką w miękką zabawkę, początkowo ze złością, ale stopniowo z radością, rozkoszą i humorem. Wypracowuje stabilny rytm. Matka wpada w swój rytm i mówi: „kaaaaa-bam, kaaaaa-bam”, w którym „bam” pada przy uderzeniu zaś „kaaaaa” podąża za przygotowawczym podniesieniem i dramatycznym zatrzymaniem ramienia przed upadkiem.

Dziewięciomiesięczna dziewczynka jest bardzo podekscytowana zabawką i sięga po nią. Chwyta ją, wydobywając z siebie entuzjastyczne „aaah!”, i patrzy na swoją matkę. Matka odwzajemnia spojrzenie, krzyżuje ramiona i wstrząsa swoim ciałem jak tancerka go-go. Wstrząs trwa tylko tyle, ile „aaaah!” jej córki, ale jest ekstatyczny, radosny i intensywny.

Stern analizuje takie przypadki wzajemnego oddziaływania pod względem intensywności, czasu i kształtu. Rozbija te jakości, opisując bardziej szczegółowo, jak matka odpowiada „całkowitej intensywności”, „konturowi intensywności”, „tempu”, „rytmowi”, „długości” i „kształtowi” dynamiki niemowlęcia (Stern 1985, s. 54, 138-161). Jak widać, niezależnie od dźwięków, doświadczenia odznaczają się dynamiką. W tym kontekście Stern opisuje coś, co określa jako „wpływy ży- 
wotności”; określenia takie jak „znikanie”, „ulotność”, „wybuchowy”, „wyciągnięty" itp. podkreślają dynamikę kinetyczną. Kolejnym wartym uwagi elementem jest to, że niezależnie od sposobu wpływu, czy to fonologicznego, czy ustnego, czy też kinetycznego, nie chodzi tu o imitację, ale o dynamikę - tworzoną przez niemowlę i matkę wraz z jakąś formą ruchu ciała. W każdym przypadku dynamika kinetyczna w sposób znaczący wpływa zarówno na niemowlę, jak i na matkę. Niemowlę i matka są zharmonizowani kognitywnie, afektywnie i kinetycznie. Razem, we wspólnym odczytaniu tej dynamiki, tworzą harmonijne synergie znaczącego ruchu. Te ontogenetyczne realia życia mają fundamentalne znaczenie. Zwłaszcza w tym, na co wyraźnie wskazują nad wyraz szczegółowe badania ontogenetyczne Sterna - naświetlając, poprzez wpływy żywotności i afirmującą/harmonizującą odpowiedź, właśnie ruch oraz intymny związek między poznaniem i ruchem oraz emocjami i ruchem.

Tę drugą relację wymieniam w kategoriach dynamicznej spójności (Sheets-Johnstone 1999, 2009). Rozpoznanie formalnej, dynamicznej spójności emocji i ruchu to rozpoznanie zjawiska całego ciała. Nie może być inaczej, gdy emocje i ruch są poszczególnymi zjawiskami przestrzenno-czasowo-energetycznymi całego ciała. Przed rozważeniem konkretnego problemu „ucieleśnionej symulacji” w odniesieniu do ruchu i tańca oraz do sztuki ogólnie, wziąwszy pod uwagę kontekst całego ciała, warto rozważyć badania naukowe innego psychiatry dziecięcego i psychologa klinicznego. George Downing stawia istotne pytanie dotyczące emocji, a mianowicie - czy powinniśmy skupić się „na twarzy czy na ciele jako całości, kiedy myślimy o emocjach?" (Downing 2005, s. 429). Jego pytanie jest zakorzenione w klarownym kontekście czasu teraźniejszego. Jak zauważam gdzie indziej (Sheets-Johnstone 2008, s. 460):

Kiedy Downing próbuje pokazać, jak „strategie badań ograniczone do twarzy mogą marginalizować zjawiska, które w rzeczywistości zasługują na większą uwagę" - kieruje nas z pewnością $\mathrm{w}$ stronę ponownego rozważenia nie tylko segmentarycznego spojrzenia na ciało i emocje, ale spojrzenia przynależnego tylko dorosłym i rozwojowo niespójnego.

Downing z uwagą obserwuje: „Mówiąc afektywnie, niemowlęta są istotami w pełni cielesnymi od samego początku" (Downing 2005, s. 429). Dlaczego zatem dorosłe istoty ludzkie często tracą w swej pełnej cielesnej afektywności odczucie zmystu ciata? Dorośli często nie rozpoznają kinetycznej dynamiki emocji, ponieważ utracili kontakt z emocjami w sensie poznania pełnego ciała, postrzegając emocje jako stany bycia lub jak nic ponad dyskretne cielesne odczucia.

Gdy wybuchamy złością, gdy zaczynamy śpiewać, gdy zniewala nas przerażenie, wahamy się mówić, skręcamy się z żalu, odwracamy się w odrazie itd.; empirycznie widać nie tylko, że emocje są kinetycznymi manifestacjami uczuć całego ciała, ale że emocje są kinetycznie różne w sensie kinestetycznym, cieleśnie odczuwalnym, i kinetycznym, cieleśnie zauważalnym. Są więc opisowo odrzucal- 
ne. Uczucia rzeczywiście mogą nas unieść, mogą sprowadzić nas na ziemię, mogą wprawić nas w zawirowanie, mogą być pokrętne, zabierając nas do innego świata. Somatyczne terapie uzdrawiające mogą zatem w zrozumiały sposób doprowadzić nas do dogłębnego docenienia terapeutycznego znaczenia ruchu. Mój odczyt na konferencji American Dance Therapy Association w 2009 roku miał w tytule pytanie: „Dlaczego ruch jest terapeutyczny?”. Pierwszą z siedmiu zaproponowanych przeze mnie odpowiedzi był argument, że ruch obwieszcza życie (Sheets-Johnstone 2010, s. 2-3). Nie tylko przychodzimy na świat w ruchu, ale więcej - dbałość o kinestetycznie odczuwaną dynamikę jakościową naszego ruchu ma zdolność pobudzenia odczucia żywotności.

Że ruch ma taką moc - że ruch obwieszcza życie - rezonuje z klarowną obserwacją Merce Cunningham:

Musisz kochać taniec, aby się z nim trzymać. Nie daje nic w zamian, nie pozostawia po sobie manuskryptów, żadnych obrazów do wieszania na ścianach czy wystawiania w muzeach, żadnych wierszy do druku i sprzedaży, nic poza tą pojedynczą ulotną chwilą, kiedy czujesz, że żyjesz. Taniec nie jest przeznaczony dla niestabilnych dusz (Cunningham 1968, niepaginowany).

To samo można z pewnością powiedzieć nie tylko o tańcu i ruchu będącym afirmacją życia, ale i o samym życiu: także i ono nie jest dla niestabilnych dusz. Jakkolwiek byśmy nie planowali, co zrobimy dziś, jutro lub pod koniec tygodnia - nasza przyszłość jest zawsze niepewna, nieprzewidywalna. Nasze próby nadania stabilności nie zawsze są skuteczne, nie tylko w odniesieniu do przyszłości, ale $\mathrm{w}$ odniesieniu do rozwiązywania trudnych problemów, takich jak ponad 350-letnia dychotomia umysłu i ciała, wraz z leksykalnymi plastrami, dokładnie takimi, jak obecne użycie terminu „ucieleśnianie” w celu załatania separacji i określenie umysłu „ucieleśnionym umysłem”. W tym kontekście należy przypomnieć o spostrzeżeniu Darwina: „Doświadczenie pokazuje, że problem umysłu nie może zostać rozwiązany atakiem na samą cytadelę - umysł jest funkcją ciała - musimy zatem przyjąć pewną stabilna podstawę dla sporu" (Darwin 1987, s. 564). Rzekłabym, że „stabilna podstawa”, dzięki której można wykazać, że „umysł jest funkcją ciała", to ruch, który oczywiście nie jest przeznaczony dla niestabilnych dusz - skoro w rzeczy samej ruch nie pozostanie nieruchomy! Kiedy koncentrujemy uwagę, obserwujemy, że ruch opisuje nie tylko ciała, ale także sam umysł.

Liczne teksty buddyjskie portretują i potwierdzają poprzez doświadczenie ten egzystencjalny fakt życia. Na przykład Joseph Goldstein i Jack Kornfield, wyświęceni mnisi, pytali: „Co widzimy, gdy patrzymy na umyst?”. Odpowiedź brzmi:

Stałą zmianę. To jak koło zamachowe wirujących myśli, emocji, obrazów, historii, upodobań, niechęci i tym podobnych. Bezustanny ruch, wypełniony planami, pomysłami i wspomnieniami. Dostrzeżenie tego wcześniej nieświadomego strumienia wewnętrznego dialogu jest dla wielu osób pierwszym wglądem w praktykę. 
Mark Epstein, praktykujący zachodni psychiatra, który szkolił się jako mnich w Azji, podobnie pisze o „stałej zmianie”, opisując medytację jako przeciwstawienie tego, co nazywa „codziennym umysłem”:

Medytacja jest bezwzględna w sposobie ujawniania surowej realności naszego codziennego umysłu. Stale pomrukujemy, mamroczemy, knowamy lub gdybamy pod nosem: pocieszając się, przewrotnie, cichymi głosami. Większość naszego życia wewnętrznego charakteryzuje ten rodzaj pierwotnego procesu; niemal infantylny sposób myślenia: „Lubię to”, „Tego nie lubię". „Zraniła mnie”. „Jak mogę to zdobyć?” „Tego więcej”. „Tamtego mniej”.

Nyanaponika Thera, mnich cejloński, zauważa dalej w odniesieniu do medytacji, że „Czysta Uwaga wprowadza porządek do nieuporządkowanych zakątków umysłu. Pokazuje liczne, niejasne i niepełne spostrzeżenia, niedokończone myśli, pomieszane idee, stłumione emocje itp., które codziennie przechodzą przez myśli”. Krótko mówiąc, buddyjskie egzystencjalne prawdy o umyśle są pełne doświadczalnych opisów umysłu w ruchu. Ich uzupełnieniem są obserwacje fenomenologiczne. Edmund Husserl, prekursor fenomenologii, opisuje, jak ruch podziela naturę umysłu, stwierdzając, że:

Świadomość świata jest w ciągłym ruchu; jesteśmy świadomi świata zawsze poprzez ten czy inny przedmiot, poprzez zmiany sposobów bycia świadomym (intuicyjny, nieintuicyjny, zdecydowany, niezdecydowany itp.), a także w zmianach uczuć i działan - w sposób powołujący całkowitą sferę uczuć i czyniący przedmioty uczuć tematycznymi i nietematycznymi; w tym odnajdujemy nas samych, zawsze i nieuchronnie należących do sfery emocjonalnej, zawsze funkcjonujących jako przedmioty działań; ale tylko niekiedy tematycznie obiektywnych - jako przedmioty własnych zainteresowań (Husserl 1970, s. 109).

To, co Husserl próbuje określić w odniesieniu do naszej świadomości świata będącego w ciągłym ruchu, jest naszym wspólnym niedostrzeżeniem owego „stałego ruchu", to nasz rzeczywisty przepływ świadomości, nie tylko w odniesieniu do obiektów ziemskich, ale w odniesieniu do naszych uczuć, zarówno afektywnych, jak i kinestetycznych. Uprawiając fenomenologię, to znaczy praktykując metodologię fenomenologiczną, widzimy, że to, co jest „dane” na najbardziej podstawowym poziomie $\mathrm{w}$ odniesieniu do naszego doświadczania nas samych w codziennym, świadomym życiu, to zapoznana odczuwalna dynamika - na przykład podnoszenia torby zakupów, grabienia liści czy wzdragania się na widok wypadku, ekscytacji perspektywą spotkania itd. (Sheets-Johnstone 2006a). Te zapoznane odczuwalne dynamiki są podobne do motywów, mających swoje odmiany, zależne od okoliczności: torba zakupów może być lekka lub ciężka, nasza ekscytacja perspektywą spotkania może być podszyta radością lub obawą. W świetle tych odczuwalnych dynamik świadomość, będąca „w ciągłym ruchu” 
(Husserl 1970, s. 109), nie jest metaforyczną czy w inny sposób figuratywną świadomością, ale dosłownie animowaną świadomością rezonującą kinestetycznie i uczuciowo w ciągłej dynamice samego życia. Precyzując - animowane istoty są rzeczywiście animowane, animowane na wskroś. Są w ruchu nie tylko w imieniu percepcji świata, ale w imieniu projektów, obrazów, uczuć, wspomnień i tym podobnych, co na bardziej fundamentalnym poziomie analizy oznacza, iż są one w ruchu nie tyle na zasadach zakresów odczuć, jak opisuje je Husserl (Husserl 1973, s. 97), co na zasadach zakresów dynamicznych schematów (Kelso 1995; Kelso, Engstrøm 2006; Sheets-Johnstone 2010a, 2010b). Ostatecznie potwierdza to jedynie to, co potwierdza sam Husserl: nie jesteśmy tylko zwyczajnymi organizmami, ale $\dot{z} y w y m i$ organizmami.

W jaki sposób te drobiazgowe opisy umysłu i świadomości są zgodne z „ucieleśnionymi umysłami” i „ucieleśnieniami” w ogóle? Mówiąc zwięźle - nie są, ponieważ ich daleko idące wyjaśnienia poddają w wątpliwość wyrażenia takie jak „ucieleśnione umysty”. Ucieleśnienia nie mogą się równać animacji. Widzimy tę dysharmonię, ten brak dopasowania do drobno przesianych doświadczalnych rzeczywistości, poprzez krytyczne spojrzenie na wcieloną symulację.

\section{Ucieleśniona symulacja}

Symulacja emocjonalna związana jest $\mathrm{z}$ neuronami lustrzanymi w mózgu. Odkrycie ich przez neurobiologów z Uniwersytetu Parmeńskiego jest znaczące, należy jednak zauważyć, że nie rodzimy się z neuronami lustrzanymi. Innymi słowy, nie rodzimy się z repertuarem ruchów, których nigdy wcześniej nie doświadczyliśmy. Gdyby tak było, wyłanialibyśmy się z macicy, chyląc z uznaniem czoła położnym, dziękując im za pomoc $\mathrm{w}$ wyprowadzeniu nas z macicy do świata, nie mówiąc już o naszych matkach, które nosiły nas przez dziewięć miesięcy. Równie istotne jest zwrócenie uwagi na niezwykle ważne przeoczenie. We wstępnych badaniach mających na celu ustalenie, czy neurony lustrzane istnieją zarówno u ludzi, jak i makaków, Rizzolatti, Fogassi i Gallese, główni neurobiolodzy z Parmy, nie wykonali badań tomograficznych w celu określenia aktywności neuronów w mózgach ludzkich - wykorzystali badania nerwowo-mięśniowe. Gładko przebiegają nad tym faktem w swoim specjalistycznym artykule z 2006 roku, opublikowanym w czasopiśmie „Scientific American”, zatytułowanym Mirrors in the Mind (Lustra w umyśle), który przedstawia zaplecze i podsumowanie ich dotychczasowych ustaleń. Opisując swoje pierwsze eksperymenty z osobami, które miały na celu określenie, „,czy system neuronów lustrzanych istnieje również u ludzi”, stwierdzają:

Wolontariusze obserwujący eksperymentatora chwytającego przedmioty lub wykonującego bezcelowe gesty ramionami odnotowali zwiększoną aktywność ner- 
wową w dłoniach i mięśniach ramion, które uczestniczyły w tych samych ruchach; sugeruje to odpowiedź neuronów lustrzanych w obszarach motorycznych mózgu (Rizzolatti i in. 2006, s. 58).

Sama sugestia „odpowiedzi neuronów lustrzanych w obszarach motorycznych mózgu" i w konsekwencji systemu neuronów lustrzanych w mózgu człowieka jest tym, co się dla nich liczy. W związku z tym pomijają oni kinestetycznie interesujące odkrycie ze względu na chęć zidentyfikowania „dokładnych obszarów mózgu", które są aktywowane, gdy wolontariusze obserwują to, co określają jako „akty motoryczne” (Rizzolatti i in. 2006, s. 58).

„Ucieleśniona symulacja” to termin, który Gallese i współpracownicy wykorzystują do określenia działania neuronów lustrzanych. Stwierdzają, że neurony lustrzane umożliwiają nam zrozumienie cudzych „aktów motorycznych”, pozwalając symulować w sposób cielesny działanie innych osób. Ucieleśniona symulacja stwarza jednak szczególny problem nie tylko w odniesieniu do działań innych w życiu codziennym, ale w odniesieniu do ruchu i tańca, o czym wspomniano wcześniej, a właściwie do sztuki w ogóle. Aby „mechanizmy” w postaci neuronów lustrzanych były miejscem urzeczywistnienia symulacji, celem określenia ich mianem „podbudowy” odbioru sztuk wizualnych, umniejsza się reakcję zarówno na formę, jak i zawartość dzieł sztuk wizualnych do określonych rozbłysków neuronów w naszych mózgach. To właśnie poprzez ominięcie „podbudowy” tej „podbudowy”, a mianowicie tych rzeczywistych doświadczeń dotykowo-kinestetycznych i inwariantów morfologii człowieka, takie doświadczenia stają się możliwe. Kiedy jednak weźmiemy pod uwagę długotrwałe formacje neuronalne, apoptozę i łączność - które posiadają solidny grunt w literaturze neurologicznej (np. Baars, Gage 2010; Edelman 1992) - ani nasuwająca się kwestia pochodzenia nie może zostać zbyta bez odpowiedzi, ani także nie można ufać temu, co Gallese i współbadacze odkryli pod postacią „zwiększonej aktywacji mięśni”. Jak wcześniej szczegółowo wykazałam, wzmożona aktywność mięśni wspiera, a nawet potwierdza ogólną tezę, że neurony lustrzane są rezultatem korporealno-kinetycznych i dotykowo-kinestetycznych inwariantów. Innymi słowy - dyrygowana kinestetycznie, koordynowana dynamika własnego ruchu jest fundamentem tego, co jest poręcznie klasyfikowane pod hasłem „symulacji wcielonej”, to znaczy tego, co leży u podstaw opisywanej przez grupę parmeńską zdolności do pojmowania „aktów motorycznych” innych osób. Reasumując, neurony lustrzane są warunkowane przez nasze własne kinestetycznie doświadczane ludzkie zdolności i możliwości ruchu, a także od nich uzależnione. Jednakowoż jest jeszcze jeden ważny element w kwestii ruchu i tańca i sztuki w ogóle.

Kiedy widzimy, jak inni poruszają się na koncercie, czyli gdy oglądamy spektakl taneczny, nasze neurony lustrzane nie wykonują podskoków, battements, salt, piruetów itd. Nasze doświadczenie jest ugruntowane i generowane nie w symulacjach, ale $w$ dynamice. Zostajemy wplątani $\mathrm{w}$ dynamikę samego ruchu, który 
jest przed nami, tak jak jesteśmy wplątani w dynamikę ruchu, gdy wykonujemy taniec. W trakcie codziennego życia zazwyczaj nie koncentrujemy się na dynamice naszego ruchu; jesteśmy zazwyczaj uważniejsi funkcjonalnie niż uważni kinestetycznie. Jesteśmy zajęci na przykład zamiataniem podłogi albo pisaniem listu lub wiązaniem sznurowadła, czy też obracaniem kierownicą samochodu, aby skręcić - i tak dalej. W naszym wcześniejszym życiu skrupulatnie nauczyliśmy się zamiatania, pisania, wiązania sznurowadła i manewrowania kierownicą. Słowem, nauczyliśmy się naszych ciał i nauczyliśmy się poruszać. W ten sposób wypracowaliśmy pewne nawyki, pewne sposoby robienia rzeczy, które stały się nam znane. Te sposoby robienia rzeczy zostały wyryte $w$ naszych ciałach poprzez ich dynamikę kinetyczną: nasz codzienny chód przebiega z pewną charakterystyczną dynamiką, którą inni postrzegają w rzeczy samej jako „nasz styl”. Także nasz śmiech wybrzmiewa $\mathrm{z}$ pewną rozpoznawalną dynamiką, którą inni postrzegają jako „nasz styl”. Sposób, w jaki szczotkujemy zęby, przebiega jednak z pewną dynamiką, która tylko dla nas samych jest wyjątkowa. Podczas gdy inni nie są obeznani z tą dynamiką, my wręcz przeciwnie - bo nawet jeśli nie koncentrujemy się na niej każdego ranka i nie zwracamy uwagi na jej odrębność, z łatwością rozpoznamy, gdyby ktoś inny szczotkował nasze zęby: doświadczylibyśmy w naszych ustach zupełnie innej dynamiki! Jakkolwiek dyskretna by nie była, dynamika ta obwieściłaby swą obcość przez swój wyraźny, różniący się przestrzennie-czasowo-energicznie przebieg.

Kiedy zaczynamy od podstawowej natury życia, od uczenia się naszych ciał i poruszania, musimy zacząć od animacji. Podobnie jak zaczynamy od animacji, gdy bierzemy pod uwagę fakt, że my ludzie jesteśmy jednym z ponad 999000 gatunków w królestwie zwierząt. Biorąc pod uwagę zarówno ontogenetyczne, jak i ewolucyjne realia, dojdziemy do przekonania, że podstawowe pojęcia ludzkie mają swój początek w ruchu: dalekie i bliskie, ta i tamta strona, szybko i powoli, słabość i siła, nagłość i trwałość itd. Te nielingwistyczne, cieleśnie [corporeal] tworzone pojęcia mają swoje pochodzenie w ruchu, ponieważ ruch jest zjawiskiem przestrzennym, czasowym i energicznym. Jak wspomniano wcześniej, ruch nie występuje jedynie $w$ przestrzeni i $w$ czasie, ale tworzy własną przestrzeń i własny czas, tak jak tworzy własny schemat energii. Jego całkowita realność jest dynamiką czaso-energio-przestrzeni. Na przykład rysunek ósemki w powietrzu ma miejsce $w$ przestrzeni przed nami, ale rysunek ósemek przedstawia swój własny układ przestrzenny, swoją własną małość lub wielkość czy ich wariacje, swoje własne pionowe lub poziome kontury i ich odmiany kierunkowe itd. Rysowanie ósemek w powietrzu odbywa się także i w czasie, ale rysunek ósemki przedstawia swój własny czasowy wzór, własną prędkość lub niespieszność i ich odmiany - akcenty, przerwy, nagłe lub zamierzone zmiany itd. Nasze ciała są morfologia$m i-w$-ruchu, rezonują kognitywnie w świecie, ponieważ same w sobie rezonują w sposoby fundamentalnie konceptualne. Mówiąc krótko, samodzielny ruch tworzy podstawowe pojęcia ludzkie, pojęcia cielesne [corporeal], na podstawie 
dynamicznej struktury samego ruchu. Aby bardziej docenić ten fakt, możemy przeanalizować tę dynamiczną strukturę, wyjaśniając krótko, lecz konkretnie jakościową dynamikę nieodłącznie związaną z ruchem.

$\mathrm{Z}$ jakimkolwiek ruchem powiązane są cztery jakości. Po pierwsze, jakość napięciowa, która $\mathrm{z}$ pewnością może się różnić $\mathrm{w}$ trakcie ruchu, ale wyróżnia ruch jako płynący z pewną energią lub siłą - jak przy otwieraniu drzwi powoli, a następnie zatrzaskiwaniu ich zdecydowanie. Po drugie, jakość linearna, która obejmuje zarówno zmieniający się linearny plan ciała $\mathrm{w}$ ruchu, jak i linearny wzór opisany przez ruch. Po trzecie, jakość otoczenia, obejmująca zmieniający się obszar ciała podczas poruszania się oraz obszar samego ruchu. Po czwarte w końcu, jakość planowana, która opisuje sposób, w jaki energia lub siła są zwolnione, tak jak w przypadku powolnego machnięcia ręką nad głową i jej nagłego spuszczenia na bok lub w ciągłym ruchu wahadłowym w przód i w tył. Jakości te można oddzielić tylko analitycznie. Każda $\mathrm{z}$ nich zawarta jest w jakimkolwiek ruchu. Ich obecność jest podstawą naszego opisu chodu jako niepewnego lub zdecydowanego. Stanowią składową cech, które sprawiają, że chód jest powolny i niepewny lub zdecydowany i stanowczy. W celu docenienia ich złożoności można jednak rozważyć cechy każdego ruchu osobno. Rozważmy na przykład pozornie prosty akt biegu. Ten tak zwany „akt” jest jakościowo złożonym ruchem z punktu widzenia samej jakości linearnej. Musimy tylko skierować naszą uwagę na trzy wysoce odrębne, ale równocześnie linearne wzorce naszego ciała w biegu: nasze stopy opisują wydłużony, linearny, okrężny wzór; nasze ramiona opisują linearny wzór w przód i w tył; nasze całe ciało opisuje linearny wzór w górę i w dół.

Jeśli zwrócimy uwagę na ruch - to znaczy zaprzestaniemy kategoryzować go w ramach „aktów”, „zachowań” czy „wcielonych działań” i zważymy na kinetyczne realia samego ruchu - odkryjemy wówczas podstawowe pojęcia nieodłącznie związane z ruchem, dokładnie tak, jak w powyższym przykładzie linearnych wzorców w biegu, w których odkryliśmy koncepcje kierunkowe, czyli okrężność, przód i tył, górę i dól. W podobny sposób możemy mówić o linearnym projekcie ciała pod względem jego pionowości, skręcenia lub przekątności. O konstrukcji przestrzennej ciała pod względem jego zwięzłości lub ekspansywności, wliczając wszystkie możliwości między tymi ekstremami. O wzorze przestrzennym ruchu, czyli obszerności i zakresie jego zasięgu, małym czy dużym rozmiarze czy kombinacjach możliwości między tymi ekstremami. O jakości napięciowej dowolnego ruchu - od słabego do silnego. O jakości planowej ruchu, to znaczy o tym, czy jest on płynny, gwałtowny, strzelisty czy opadający, albo też odznaczający się kombinacją tychże. Pojęcia pionowości, ekspansywności, wielkości, słabości, trwałości itd. wywodzą się z podstawowej rzeczywistości ruchu. Pochodzą one przede wszystkim z doświadczeń kinestetycznych. Doświadczeń, które odnoszą nas do niemowlęctwa, kiedy byliśmy niewerbalni, ale wyczuleni na kinetykę życia. Kiedy psychiatra dziecięcy René Spitz stawiał pytania dotyczące sposobu, w jaki niemowlęta odróżniają przedmioty żywe od przedmiotów martwych, badania do- 
prowadzily go do odpowiedzi w postaci „dwóch bodźców wzrokowych, [które] niezawodnie kierują uwagę dziecka i jego reakcję na to, co żywe”. Wizualne bodźce to "ludzka twarz i oczy” z jednej strony i „postrzeganie wszelkiego rodzaju ruchu" z drugiej (Spitz 1983, s. 147-149). W pewnym sensie odpowiedź można ograniczyć do jednostkowej uwagi, uwagi na ruch, a to dlatego, że ludzka twarz, szczególnie oczy, rzadko są w bezruchu. Ruch, z racji swojej dynamiki, swojej żywotności, jest intrygujący. Czy dziwić może zatem, że stanowi fundament podstawowych ludzkich koncepcji, cieleśnie wytworzonych koncepcji wywodzących się z naszych doświadczeń ruchu?

Wcielona symulacja pozostaje bezsilna, próbując wyjaśnić źródła naszego rozumienia ruchu innych. Bezsilna, ponieważ pomija fundamenty tego rozumienia, a mianowicie ruch, skwapliwie doświadczaną dynamikę ruchu i jakości, które tworzą tę dynamikę, oraz koncepcje generowane w nich i poprzez nie.

\section{Strategie choreograficzne $w$ badaniach i twórczości artystycznej}

Neuronalna choreografia jest $\mathrm{w}$ istocie błędną wskazówką, gdyż choreografia określa ruchy ustawione, podczas gdy neuronalne działanie nie musi być ustawione. Nawyki są nawykami, ale różnią się w zależności od okoliczności. Istnieją zatem różnice w neuronalnej „choreografii”. Ponadto prawdopodobieństwo związków neuronowych jest kreowane w kategoriach codziennych wahań, niespodzianek itd. Animowane formy życia nie są automatami! Neuronalna choreografia nie jest zatem kwestią „to się tutaj dzieje, a to dzieje się tam”, ale kwestią skoordynowanej dynamiki „potencjałów działania”, aktywacji neuronów, sekwencyjnych synaps itd.

Proces badań w dziedzinie neurologii jest szczególnie interesujący pod tym względem, ponieważ sposób, w jaki są postrzegane i później badane neurony, ma ogromne znaczenie. W artykule zatytułowanym Wykorzystanie rysunków komórek mózgu do eksponowania wiedzy $w$ dziedzinie neurologii: odkrywanie granic kultury eksperymentalnej [Using Drawings of the Brain Cell to Exhibit Expertise in Neuroscience: Exploring the Boundaries of Experimental Culture] David Hay i wspólautorzy szczegółowo opisują eksperyment, w którym „interweniują” w normalne wykształcenie neurobiologów. Ich interwencja polega na tym, że uczniowie rysują i poruszają się podczas trwania eksperymentu, co w sensie ogólnym pozwala na krytyczną analizę i w konsekwencji na zmianę stanu wiedzy o tym, w jaki sposób zazwyczaj pozyskują wstępną wiedzę na temat neuronów, jak ich koncepcja neuronu może się zmienić w trakcie ich edukacji i jak koncepcja neuronu ulega przeformulowaniu $w$ badaniach eksperymentalnych naczelnego neurologa. Krótko mówiąc, ich „strategia choreograficzna” zwraca uwagę na to, w jaki sposób początkowe uczenie się może ewoluować poprzez zaangażowanie ciała, edukację zo- 
rientowaną na ruch. Na przykład ich pierwsze działanie prowokuje pytanie: „Czy komórki muszą ze sobą rozmawiać, aby taki system biologiczny działał?” (Hay i in. 2013, s. 478). W związku z ingerencją w uczenie się stwierdzają: „Wniosek z ćwiczeń (który wielu uczniów spostrzegło spontanicznie) jest taki, że komórki neuronów nie rozpoznają własnej pozycji w embrionalnym mózgu ex situ, ale reagują na sygnały z tego środowiska, wyczuwając swoją pozycję w systemie" (Hay i in. 2013, s. 478). W odniesieniu do drugiej ingerencji wyjaśniają konkretnie:

Choreografowaliśmy ruch uczniów, tak że wszyscy oni stopniowo przechodzili przez laboratorium i docierali do jednego z dwóch wyznaczonych miejsc, niektórzy uczniowie docierali do nich mniej lub bardziej wyjątkową trajektorią, podczas gdy ścieżki innych uczniów były współdzielone (według stopni wspólnej historii życia), a niektóre trajektorie wykazywały jedno lub kilka przecięć z innymi, pozostałe zaś nie miały żadnego (Hay i in. 2013, s. 478).

W istocie Hay i in. zmieniają to, co określają jako „kulturę wizualną” (Hay i in. 2013, 471), w kinetycznie żywą kulturę, zarówno przez rysunek, jak i formę przemieszczania się. Choć nie opisują tego eksperymentu w takich kategoriach, to eksperyment wyraźnie angażuje studentów w odmienny sposób niż zwykłe prezentowanie neuronów w podręcznikach: eksperyment angażuje uczniów do myślenia w ruchu. Krótko mówiąc, są zaangażowani, aby myśleć nie w kategoriach przestrzennie pointylistycznych, ale w kategoriach ruchomej formy, żywej kinetycznej istoty. Warto podkreślić, że sam projekt eksperymentu - sposób, w jaki Hay i inni zaplanowali eksperyment - był przykładem myślenia w ruchu. W rzeczywistości, choć powszechnie nie jest to za takie uznawane, planowanie dowolnego eksperymentu naukowego, sposób jego sekwencjonowania, logika, z którą się rozwija - w skrócie: jego projekt - jest kwestią myślenia w ruchu (zob.: Sheets-Johnstone 1981, s. 2010b).

Choreografia tańca jest oczywiście myśleniem w ruchu. Szczególnie jest to myślenie w kategoriach wewnętrznej dynamiki jakościowej ruchu i sposobu, w jaki dynamika wypływa z własnej, wewnętrznej logiki kinetycznej - czy i jak zmienia się, mutuje, powtarza itd. W rezultacie, niezależnie od szorstkości, gładkości, wybuchowości lub kurczliwości dowolnego ruchu, wcale nie jest on samodzielny, ale jest integralną częścią całości, która jest ogólną dynamiką samego tańca. Uczenie się tańca jest więc również myśleniem w ruchu i przez to także uczeniem się jego jakościowej dynamiki, uczeniem się jej od początku do końca, ale znowu w ten sposób, że rozwija się pojedyncza dynamika. Elokwentny opis choreografii i uczenia się tańca dał Merce Cunningham. Na temat swojego tańca „Untitled Solo” pisze:

Opracowano dużą gamę ruchów, oddzielną dla każdego z trzech tańców. Ruchy w ramionach, nogach, głowie i korpusie, które były odrębne i zasadniczo rozciągające $\mathrm{w}$ charakterze i poza normalną lub spokojną równowagą ciała. Oddzielne ru- 
chy były rozmieszczone w ciągu w przypadkowy sposób, pozwalając na nakładanie (dodawanie) jednego lub więcej, każdy z własnym rytmem i długością. Ale każdy był włączony w ciąg, gdy mogłem nosić go wystarczająco długo, jak ubranie (Cunningham 1968).

Ciągłość formy, integralna całość tańca, była kwestią przesunięcia w dynamice i poznania nowej dynamiki - wymagającej kinetycznej logiki. Gdy uda mu się zatańczyć, Cunningham nie porusza się już w „dużej gamie ruchów”, ale, jak mówi, „nosi je jak ubranie”. W efekcie nie przechodzi pewnych ruchów, które „wymyślił”. Jeśli „nosi on ruch jak ubranie”, to nie idzie przez formę, forma przechodzi przez niego. Rzeczywiście - jeśli ruch nie przechodzi przez niego, taniec nie istnieje.

Podsumowując, gdy weźmie się pod uwagę, że ruch jest podstawową rzeczywistością życia, trudno się dziwić, że jest on też integralną częścią strategii choreograficznych, zarówno w dążeniu do wiedzy naukowej, jak i w tworzeniu dzieł sztuki, a myślenie w ruchu jest podstawą obu.

Przekład: Konrad Zieliński

\section{Bibliografia}

Arystoteles (1990), Fizyka, tłum. K. Leśniak [w: ] Arystoteles, Dzieła wszystkie, tom II, PWN, Warszawa.

Baars B.J., Gage, N.M. (2010), Cognition, Brain, and Consciousness: Introduction to Cognitive Neuroscience, Elsevier, Amsterdam.

Cunningham M. (1968), Changes: Notes on Choreography, Something Else Press, New York.

Darwin Ch. (1987), Charles Darwin's Notebooks, 1836-1844, P.H. Barrett, P. J. Gautrey, S. Herbert, D. Kohn, S. Smith (red.), Cornell University Press, Ithaca.

Downing G. (2005), Discussion: Emotion, Body, and Parent-Infant Interaction, [w: ] Emotional Development, J. Nadel, D. Muir (red.), Oxford University Press, Oxford.

Furuhjelm M., Ingelman-Sundberg A., Wirsén C. (1977), A Child Is Born, Delacorte Press/Seymour Lawrence, New York.

Edelman G. (1992), Bright Air, Brilliant Fire: On the Matter of the Mind, Basic Books, New York.

Hay D.B., Williams D., Stahl D., Wingate R.J. (2013), Science Education, t. 97, nr 3.

Husserl E. (1970), The Crisis of the European Sciences and Transcendental Phenomenology, Northwestern University Press, Evanston (IL).

Husserl E. (1973), Cartesian Meditations, Martinus Nijhoff, The Hague.

Kelso J.A.S. (1995), Dynamic Patterns, Bradford Books/MIT Press, Cambridge.

Kelso J.A.S., Engstrøm D.A. (2006), The Complementary Nature, Bradford Books/MIT Press Cambridge. 
Rizzolatti, G., Fogassi L., Gallese V. (2006), Mirrors in the Mind, „Scientific American”, November.

Sheets-Johnstone M. (1981), Thinking in Movement, „The Journal of Aesthetics and Art Criticism" 39/4.

Sheets-Johnstone M. (1999). Emotions and Movement: A Beginning Empirical-Phenomenological Analysis of Their Relationship, „Journal of Consciousness Studies” 6, nr 1112. Także jako rozdział VIII w: Sheets-Johnstone M. (2009), The Corporeal Turn: An Interdisciplinary Reader, Imprint Academic, Exeter.

Sheets-Johnstone M. (2008), Getting to the Heart of Emotions and Consciousness, [w: ] P. Calvo, A. Gomila (red.), Handbook of Cognitive Science: An Embodied Approach, Elsevier, Amsterdam.

Sheets-Johnstone M. (2010a), Why Is Movement Therapeutic?, „American Journal of Therapy", t. 32, nr 1.

Sheets-Johnstone M. (2010b), Thinking in Movement: Further Analyses and Validations, [w:] J. Stewart, O. Gapenne, E.A. Di Paolo (red.), Enaction: Toward a New Paradigm for Cognitive Science, Bradford Book/MIT Press, Cambridge.

Sheets-Johnstone M. (2012), On Movement and Mirror Neurons: A Challenging and Choice Conversation, „Phenomenology and the Cognitive Sciences” nr 11.

Spitz R. (1983), Dialogues from Infancy, R.N. Emde (red.), International Universities Press, New York.

Stern D.N. (1985), The Interpersonal World of the Infant: A View from Psychoanalysis and Developmental Psychology, Basic Books, New York.

\section{Summary}

Whether in science or in art, choreographic strategies are grounded in movement. Thus, a kinetic dynamic is integral to choreographic strategies in both the pursuit of scientific knowledge about some phenomenon and in the creation of works of art, a kinetic dynamic that is tied to thinking in movement and to the qualitative dynamics of movement. In order to bring this foundational reality of movement to the fore, the chapter first details common practices and ways of thinking that are obstacles to its recognition, obstacles running from dictionary definitions to embodiments of all kinds. In the process of critically specifying these common practices and ways of thinking, the chapter shows how, on the basis of the inherent qualitative dynamics of movement, a dynamic congruency exists between emotions and movement and how in our everyday lives, alone and with others, we create synergies of meaningful movement. It in fact shows how both Buddhist expositions of mind and phenomenological analyses of consciousness are anchored in movement and in turn how and why talk of mirror neurons and embodied simulation are benighted scientific attempts to explain the experience of movement. The chapter then turns to paradigms of choreographic strategies in science and in art, the first detailing neuroscience research studies focusing on brain cell interactions, the second detailing Merce Cunningham's description of his approach to choreographing and learning a new solo dance. In each instance - whether a matter of science or of art - movement and the practice of thinking in movement are at the core of the choreographic strategy. 